\title{
Teaching NeuroImages: Cerebral inception
}

\section{A "brain" within a brain}

Emma Macdonald-Laurs, MBChB, Richard J. Leventer, MBBS, PhD, and Rakesh Patel, MBChB

Neurology ${ }^{\circledR}$ 2019;92:e392-e393. doi:10.1212/WNL.0000000000006820
Correspondence

Dr. Macdonald-Laurs

emma.macdonaldlaurs@

health.nsw.gov.au

\section{Figure Brain MRI}

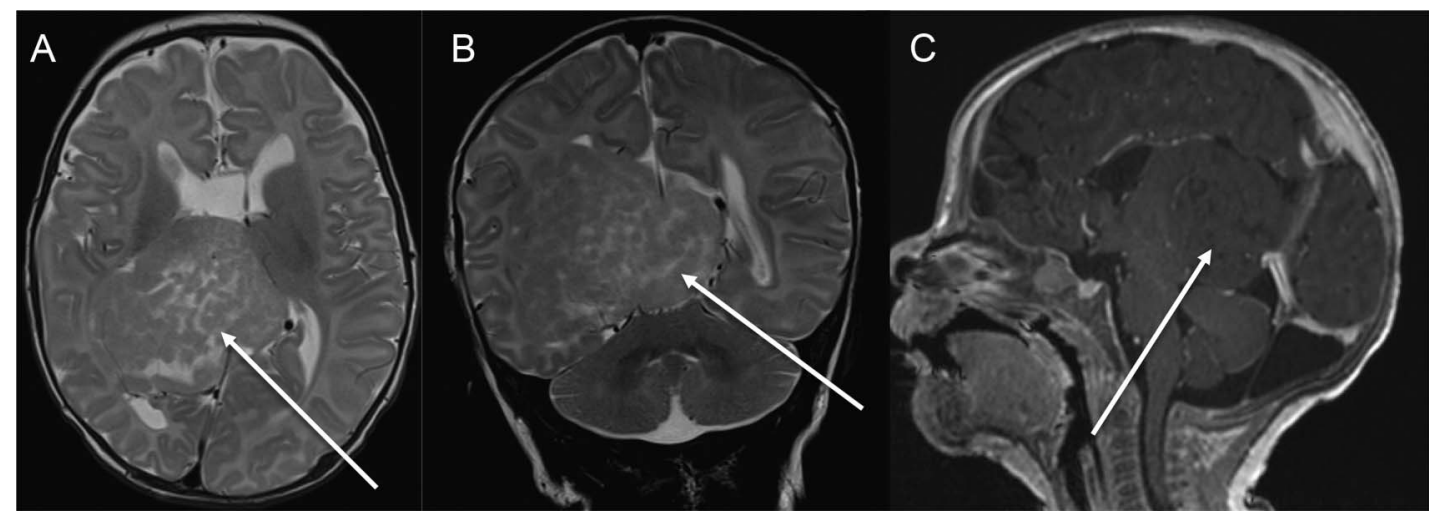

T2-weighted axial (A), T2-weighted coronal (B), and T1-weighted sagittal (C) images demonstrate a large mass within the medial aspect of the right hemisphere (temporo-parietal lobes) displacing the right ventricle. It has signal characteristics similar to normal gray and white matter with rudimentary gyration and sulcation. There was no enhancement following gadolinium administration (not shown).

An 8-week-old term infant with congenital nephrotic syndrome developed stiffening following general anesthetic. His neurologic examination and EEG were normal. MRI brain demonstrated a large mass of dysplastic brain isointense to cortex with intervening "sulcal" spaces (figure). The infant continued to have infrequent seizures.

Glioneuronal hamartomas are well-circumscribed, non-neoplastic, masses of disorganized mature neuronal and glial cells arising from abnormal neural development. ${ }^{1}$ Accompanying gray and white matter heterotopia are common. ${ }^{2}$ Glioneuronal hamartomas make up a small but significant proportion of patients operated on for drug-resistant epilepsy. ${ }^{2}$ Very large hamartomas, as described, are rare.

\section{Study funding}

No targeted funding reported.

\section{Disclosure}

The authors report no disclosures relevant to the manuscript. Go to Neurology.org/ $\mathrm{N}$ for full disclosures.

\section{References}

1. Schramm J, Kral T, Grunwald T, Blumcke I. Surgical treatment for neocortical temporal lobe epilepsy: clinical and surgical aspects and seizure outcome. J Neurosurg 2001;94:33-42.

2. Frater J, Prayson R, Morris H, Bingaman W. Surgical pathologic findings of extratemporal-based intractable epilepsy. Arch Pathol Lab Med 2000;124:p545-p549.

\section{MORE ONLINE}

\section{$\rightarrow$ Teaching slides}

links.lww.com/WNL/ A794

From Starship Children's Hospital (E.M.-L., R.P.), Auckland, New Zealand; and Royal Children's Hospital (R.J.L.), Melbourne, Australia. 
Appendix 1 Authors

\begin{tabular}{llll}
\hline Name & Location & Role & Contribution \\
\hline $\begin{array}{l}\text { Emma Macdonald- } \\
\text { Laurs, MBChB }\end{array}$ & $\begin{array}{l}\text { Starship Children's } \\
\text { Hospital }\end{array}$ & Author & $\begin{array}{l}\text { Report design and conception, project execution, interpretation of neuroimages, writing of } \\
\text { first draft, review and editing of manuscript }\end{array}$ \\
\hline $\begin{array}{l}\text { Richard J Leventer, } \\
\text { MBBS, PhD }\end{array}$ & $\begin{array}{l}\text { Royal Melbourne } \\
\text { Children's Hospital }\end{array}$ & Author & Interpretation of neuroimages, review and editing of manuscript \\
\hline Rakesh Patel, MBChB & $\begin{array}{l}\text { Starship Children's } \\
\text { Hospital }\end{array}$ & Author & Report conception, review and editing of manuscript \\
\hline
\end{tabular}

Copyright (C) 2019 American Academy of Neurology. Unauthorized reproduction of this article is prohibited. 


\section{Neurology}

\section{Teaching NeuroImages: Cerebral inception: A "brain" within a brain}

Emma Macdonald-Laurs, Richard J. Leventer and Rakesh Patel

Neurology 2019;92;e392-e393

DOI 10.1212/WNL.0000000000006820

This information is current as of January 21, 2019

\section{Updated Information \& Services}

References

Subspecialty Collections

Permissions \& Licensing

Reprints including high resolution figures, can be found at: http://n.neurology.org/content/92/4/e392.full

This article cites 2 articles, 0 of which you can access for free at: http://n.neurology.org/content/92/4/e392.full\#ref-list-1

This article, along with others on similar topics, appears in the following collection(s):

All Epilepsy/Seizures

http://n.neurology.org/cgi/collection/all_epilepsy_seizures All Pediatric

http://n.neurology.org/cgi/collection/all_pediatric MRI

http://n.neurology.org/cgi/collection/mri

Information about reproducing this article in parts (figures,tables) or in its entirety can be found online at:

http://www.neurology.org/about/about_the_journal\#permissions

Information about ordering reprints can be found online:

http://n.neurology.org/subscribers/advertise

Neurology ${ }^{\circledR}$ is the official journal of the American Academy of Neurology. Published continuously since 1951, it is now a weekly with 48 issues per year. Copyright (O 2019 American Academy of Neurology. All rights reserved. Print ISSN: 0028-3878. Online ISSN: 1526-632X.

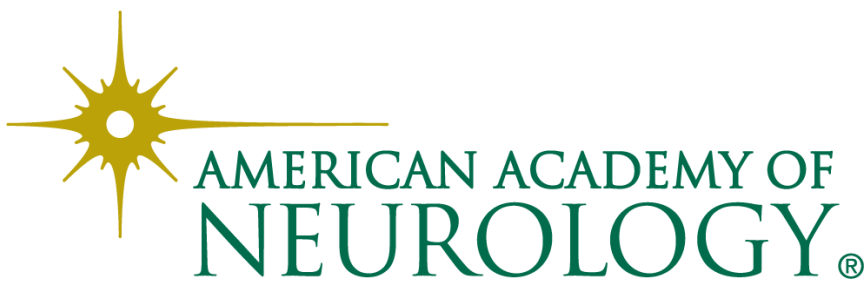

